УДК 332.02

doi: 10.15330/apred.1.15.122-132

\title{
ПЕРЕДУМОВИ ПРОВЕДЕННЯ ТА КОМПЛЕКСНІ ПРОБЛЕМИ НОВОЇ РЕГІОНАЛЬНОЇ ПОЛІТИКИ В УКРАЇНІ
}

\author{
Черкаський державний технологічний університет, \\ Міністерство освіти і науки України, \\ кафедра фінансів, \\ бул. Шевченка, 460, м. Черкаси, \\ 18006, Україна, \\ тел.: (0472)-71-10-57, \\ e-mail: finance@chdtu.edu.ua
}

\begin{abstract}
Анотація. У статті показано, що реалізація в Україні нової регіональної політики, яка базується на парадигмі нового регіоналізму, натикається на значні труднощі, в подоланні яких значна роль належить науковим розробкам. 3'ясовано, що у більшості з них недостатньо уваги приділяється оцінюванню передумов проведення нової регіональної політики в Україні та систематизації й аналізу іiі основних проблем, що потребують вирішення в сучасний період. Поставлено за мету проведення спеціального дослідження передумов та комплексних проблем нової регіональної політики в Україні.

У дослідженні використано загальнонаукові (аналізу й синтезу, логічного узагальнення, порівняльний) та економіко-статистичні (абсолютних, відносних і середніх величин, індексний, рейтингових оцінок і групування) методи. Проаналізовано передумови проведення нової регіональної політики в Україні, пов'язані 3 російською агресією, активізацією процесів глобалізації та регіоналізації, загостренням протиріч між регіонами. У зв’язку 3 цим аргументовано необхідність виокремлення та вирішення таких комплексних проблем нової регіональної політики, як: політична та економічна дезінтеграція українських регіонів; поглиблення асиметрії в соціально-економічному розвитку регіонів; поляризація економічного простору; неготовність регіонів до викликів глобалізації; невисокий рівень регіональної конкурентоспроможності й, відповідно, регіонального людського розвитку.

У статті запропоновано заходи вирішення цих проблем, що спираються не тільки на пряму допомогу центру регіонам, а й передбачають стимулювання ефективного використання їхнього ресурсного потенціалу, активізацію інноваційно-інвестиційної діяльності та підвищення міжнародної конкурентоспроможності регіонів в умовах глобалізації.

Зроблено висновок, що реалізація цих заходів має забезпечити в усіх регіонах України високий рівень людського розвитку.

Ключові слова: нова регіональна політика, дезінтеграція регіонів, міжрегіональна асиметрія, поляризація економічного простору, виклики глобалізації, регіональна конкурентоспроможність, регіональний людський розвиток.
\end{abstract}

Zakharchenko V.I.

\section{BACKGROUND TO CONDUCT AND COMPLEX PROBLEMS NEW REGIONAL POLICY IN UKRAINE}

Cherkasy State Technological University

Ministry of Education and Science of Ukraine,

Department of Finance,

Blvd. Shevchenko, 460, Cherkasy,

18006, Ukraine,

tel.: (0472) -71-10-57, 
e-mail: finance@chdtu.edu.ua

\begin{abstract}
The article shows that the implementation of a new regional policy in Ukraine, based on the paradigm of the new regionalism, runs into considerable difficulties, in which significant role belongs to scientific development. It is found that in most of them insufficient attention is paid to assessing the prerequisites for a new regional policy in Ukraine and to systematize and analyze its main problems that need to be addressed in the current period. It is aimed at conducting a special study of the preconditions and complex problems of the new regional policy in Ukraine.

The study used general scientific (analysis and synthesis, logical generalization, comparative) and economic and statistical (absolute, relative and average values, index, rating and grouping) methods. The background of the new regional policy in Ukraine related to the Russian aggression, intensification of the processes of globalization and regionalization, aggravation of contradictions between regions are analyzed. In this connection, the necessity of isolating and solving such complex problems of the new regional policy as: political and economic disintegration of the Ukrainian regions is argued; deepening asymmetry in the socio-economic development of regions; polarization of economic space; unpreparedness of regions to face the challenges of globalization; low level of regional competitiveness and, accordingly, regional human development.

The article proposes measures to solve these problems, which are based not only on direct assistance to the center of the regions, but also provide incentives for efficient use of their resource potential, activation of innovation and investment activity and enhancement of the international competitiveness of regions in the context of globalization.

It is concluded that the implementation of these measures should ensure a high level of human development in all regions of Ukraine.

Key words: new regional policy, disintegration of regions, inter-regional asymmetry, polarization of economic space, challenges of globalization, regional competitiveness, regional human development.
\end{abstract}

Вступ. 3 кінця 80-х pp. ХX ст. передові країни перейшли до реалізації нової регіональної політики, яка базується на парадигмі нового регіоналізму. В СС практична реалізація концепції проявилася у переході від моделі “Свропа регіонів” до моделі «Свропа через регіони». Перехід до нової моделі ознаменувався підвищенням значимості горизонтального підходу при вирішенні проблем регіонального розвитку, що стало можливим завдяки децентралізації влади, зростанню відповідальності регіональних і місцевих органів влади за розвиток підпорядкованих їм територій. На практиці це вилилося в перехід від прямої допомоги центру регіонам до стимулювання ефективного використання їхнього ресурсного потенціалу, активізації інноваційноінвестиційної діяльності та підвищенні міжнародної конкурентоспроможності регіонів в умовах глобалізації.

Україна, аби вписатися у світові тренди розвитку регіональної політики, також взяла на озброєння парадигму нового регіоналізму. Деякі елементи нової регіональної політики можна знайти в Концепції державної регіональної політики, затвердженій Указом Президента України від 25 травня 2001 р. № 341/2001. Але повноформатний перехід до нової регіональної став можливим після прийняття Закону України "Про стимулювання розвитку регіонів” від 8 вересня 2005 р. № 2850-IV. Це знайшло підтвердження в Державній стратегії регіонального розвитку до 2015 року, затвердженій постановою Кабінету Міністрів України від 21 липня 2006 р. № 1001. У ній як головну мету нової регіональної політики на державному рівні визначено створення умов для підвищення конкурентоспроможності регіонів як основи їхнього динамічного розвитку та усунення значних міжрегіональних диспропорцій. Досягнення цієї мети не має чітко вираженого часового горизонту, тому ця стратегія вона була пролонгована до 2020 р. Постановою Кабінет Міністрів України від 6 серпня 2014 р. № 385. Немає сумніву, що вона буде продовжена й на наступний період і що в ній будуть 
124 Захарченко В.І. Передумови проведення та комплексні проблеми...

враховані засадничі положення, визначені порядком денним асоціації України з ЄС і закріплені в Законі України “Про засади державної регіональної політики” від 5 лютого 2015 p. № 156-VIII.

Отже, в Україні іï державні і регіональні органи влади перейшли до реалізації нової регіональної політики, яка, однак, натикається на значні труднощі. У їх подоланні значна роль належить науковим розробкам.

Аналіз останніх досліджень. Значний внесок у розробку наукових засад нової регіональної політики в України зробили такі вчені, як С. Біла, М. Бутко, 3. Варналій, Б. Данилишин, М. Долішній, І. Дунаєв, Я, Жаліло, В. Загорський, Ю. Ковбасюк, В. Кравців, С. Куйбіда, А. Маєв, В. Негода, В. Нехайчук, С. Писаренко, С. Пухир, С. Романюк, I. Сторонянська, А. Ткачук, Р. Тульчинський, С. Шульц та ін. Однак у їхніх працях недостатньо уваги приділено з'ясуванню передумов проведення нової регіональної політики в Україні та систематизації й аналізу іії основних проблем.

Постановка завдання. Мета дослідження полягає у дослідженні передумов проведення нової регіональної політики в Україні, виокремленні та аналізі іiі комплексних проблем, що потребують вирішення в сучасний період.

Результати. Ситуація, що склалася в суспільному й, зокрема, економічному просторі України у зв'язку із російською агресією, активізацією процесів глобалізації та регіоналізації, загостренням протиріч між регіонами (через політичну й ментальну різновекторність поглядів населення та глибоку асиметрію рівнів соціальноекономічного розвитку) потребує врахування цих передумов при проведенні нової регіональної політики. Крім того, активна фаза реформи децентралізації вимагає проводити нову регіональну політику як окремий іiі напрям (регіональний зріз), що, зокрема, передбачає перерозподіл владних повноважень і ресурсів між центром та регіонами.

Із врахуванням складних військово-політичних та соціально-економічних передумов нова економічної політики в Україні має концентруватися на вирішенні таких її комплексних проблем:

1. Політична та економічна дезінтеграція украӥнських регіонів. Недостатність україноцентризму на регіональному рівні, особливо на Сході й Півдні країни, що пов'язано зі складною історією формування Української держави (тривалим перебуванням різних іiі частин у складі різних держав), наявністю національних та соціокультурних відмінностей, особливо релігійних і мовних, об'єктивно загострює проблеми політичної регіоналізації. Ці проблеми особливо загострилися після того як Україна заявила про свій курс на євроатлантичну інтеграцію, а українські патріоти виступили на його підтримку під час Оранжевої революції. Так, на кінець 2005 р. на питання Київського міжнародного інституту соціології - чи є поділ на Схід і Захід поділом на ворогуючі сторони, - отримує ствердну відповідь $34,7 \%$ респондентів. На Заході твердження про поділ на ворожі табори підтримали 23,9 \%, в Центрі - 29,5 \%, на Півдні - 33,5 \% і на Сході - 54 \% [1, с. 67]. Після Революції гідності у 2014 р. ситуація 3 політичним розколом регіонів на ворожі табори ще більше загострилася. Тому російські спецслужби, особливо в Криму і на Донбасі, отримали сприятливий грунт для інспірації акцій з політичної дезінтеграції України. Ввівши в дію «зелених чоловічків», регулярні війська та найманців з числа місцевих колаборантів, Росії вдалося тимчасово окупувати АР Крим та окремі райони Донецької і Луганської областей (ОРДЛО). Таким чином, на тлі історичних та соціально-культурних відмінностей українських регіонів політична, а також економічна дезінтеграція українських регіонів набула загрозливих форм.

Щодо економічної дезінтеграції регіонів України, то вона пов'язана не тільки 3 російською окупацією частини іiї території. Вона є наслідком колоніального минулого 
України, коли на іï території за замкнутими технологічними циклами вироблялося близько $20 \%$ продукції. Крім того, вона спричинена ще й катаклізмами ринкових трансформацій, поглибленням асиметрії в рівнях розвитку регіонів та нерозумінням у владних коридорах необхідності використання переваг територіального поділу й кооперації праці. Наразі тісні виробничі зв'язки збереглися хіба що між регіонами вугільно-металургійної спеціалізації - Промисловим Придніпров'ям та підконтрольними Україні районами Донбасу.

2. Поглиблення асиметрї в сочіально-економічному розвитку регіонів. За 20002017 рр. в Україні розмах міжрегіональної асиметрії (Ap) за більшістю основних показників соціально-економічного розвитку регіонів (без міст Києва і Севастополя) не тільки не зменшився, а навпаки, зріс. Розрахунок $A p$, як відношення показника передового в певному відношенні регіону до показника найбільш відсталого регіону, показав, що після 2014 р., зокрема через агресивні дії Росії, міжрегіональна асиметрія в розвитку регіонів стала ще глибшою (табл. 1).

Таблиия 1

\section{Розмах міжрегіональної асиметрії за показниками розвитку регіонів (областей ${ }^{1}$ ) України}

Table 1

The scope of inter-regional asymmetry in terms of development regions ${ }^{1}$ of Ukraine

\begin{tabular}{|c|c|c|c|c|c|c|c|c|c|c|c|c|}
\hline \multirow{2}{*}{$\begin{array}{c}\text { Показники регіонів, } \\
\text { в розрахунку на } \\
\text { одну особу } \\
\end{array}$} & \multicolumn{3}{|c|}{2000 p. } & \multicolumn{3}{|c|}{2010 p. } & \multicolumn{3}{|c|}{2013 p. } & \multicolumn{3}{|c|}{$2017^{2}$ p. } \\
\hline & $\max$ & $\min$ & $A p^{3}$ & $\max$ & $\min$ & Ap & $\max$ & $\min$ & $A p$ & $\max$ & $\min$ & Ap \\
\hline $\begin{array}{l}\text { Валовий } \\
\text { регіональний } \\
\text { продукт }^{4}\end{array}$ & Зп & Чрн & 2,69 & Днп & Чрн & 3,17 & Днп & Чрн & 3,06 & Пл & Лг & $5,69^{5}$ \\
\hline $\begin{array}{l}\text { Продукція } \\
\text { промисловості }\end{array}$ & Зп & Зк & 9,88 & Днп & Чрн & 14,1 & Днп & Чрн & 14,6 & Днп & Лг & 12,1 \\
\hline $\begin{array}{l}\text { Обсяг реалізованої } \\
\text { інноваційної } \\
\text { продукції }\end{array}$ & Днц & Кр & 121,3 & Пл & Xм & 154,9 & Пл & Рв & 28,3 & Зп & Лг & 387,2 \\
\hline $\begin{array}{l}\text { Продукція сільського } \\
\text { господарства }\end{array}$ & $\mathrm{BH}$ & Лг & 3,47 & Чрк & $\begin{array}{c}\text { Днц, } \\
\text { Лг }\end{array}$ & 4,44 & Чрк & Днц & 4,49 & $\mathrm{BH}$ & Лг & 6,22 \\
\hline Експорт товарів & Днп & $\mathrm{Tp}$ & 21,1 & Днц & $\mathrm{Tp}$ & 25,7 & Днп & Чрн & 21,5 & Днп & Чрн & 13,2 \\
\hline $\begin{array}{l}\text { Коефіцієнт покриття } \\
\text { експортом імпорту }\end{array}$ & Днц & Вл & 8,22 & Днц & Од & 8,94 & Кр & Кв & 8,48 & $\mathrm{BH}$ & Кв & 5,82 \\
\hline Капітальні інвестиції & Пл & Чрн & 6,52 & Кв & ЖТ & 4,20 & Кв & $\mathrm{Xpc}$ & 6,09 & Кв & Чрн & 6,00 \\
\hline $\begin{array}{l}\text { Прямі іноземні } \\
\text { інвестиції }\end{array}$ & Кв & Чрн & 19,6 & Днп & $\mathrm{Tp}$ & 34,4 & Днп & $\mathrm{Tp}$ & 42,9 & Днп & $\mathrm{Tp}$ & 72,4 \\
\hline $\begin{array}{l}\text { Рівень зайнятості } \\
\text { населення (у \% до } \\
\text { всього) }\end{array}$ & $\mathrm{BH}$ & Чрн & 1,47 & Днп & $\mathrm{I} \Phi$ & 1,20 & Хрк & $\mathrm{I} \Phi$ & 1,15 & Хрк & Лг & 3,47 \\
\hline $\begin{array}{l}\text { Середньомісячна } \\
\text { заробітна плата }\end{array}$ & Днц & $\mathrm{Tp}$ & 2,17 & Днц & $\mathrm{Tp}$ & 1,54 & Днц & $\mathrm{Tp}$ & 1,59 & Днц & $\mathrm{Tp}$ & 1,40 \\
\hline $\begin{array}{l}\text { Наявний доход } \\
\text { населення }\end{array}$ & Днц & Чрн & $1,60^{6}$ & Днц & Зк & 1,68 & Днц & Зк & 1,73 & Днп & Лг & 3,49 \\
\hline
\end{tabular}

Примітки:

${ }^{1}$ Використано такі скорочення назв областей: Вн - Вінницька, Вл - Волинська, Днц - Донецька, Днп - Дніпропетровська, Жт - Житомирська, Зк - Закарпатська, Зп - Запорізька, ІФ - ІваноФранківська, Кв - Київська. Кр - Кіровоградська, Лг - Луганська, Од - Одеська, Пл - Полтавська Рв Рівненська, Тр - Тернопільська, Хрк - Харківська, Хрс - Херсонська, Хм - Хмельницька, Чрк Черкаська, Чрн - Чернівецька;

${ }^{2}$ Дані наведено без урахування тимчасово окупованих територій АР Крим та ОРДЛО;

${ }^{3} \mathrm{Ap}$ - розмах міжрегіональної асиметрії за показниками розвитку регіонів;

43а 2000 р. - валова додана вартість;

${ }^{5}$ Дані за 2016 рік; 
126 Захарченко В.I. Передумови проведення та комплексні проблеми...

\author{
${ }^{6}$ Дані за 2001 рік. \\ України. \\ Джерело: складено автором на основі [2, с. 10, 20, 56, 63, 69, 75] та даних Держслужби статистики
}

За основним показником економічного розвитку - валовим регіональним продуктом (ВРП) на одну особу - та й іншими показниками особливо «просіла» Луганська область, точніше підконтрольна Україні її частина. Частково це пов'язано 3 тим, що в межах України залишилася її менш розвинена частина, але більшою мірою через розв’язану Росією війну на Сході країни. Окуповані українські території (через пограбування їх загарбниками, вивіз матеріальних цінностей, особливо сучасного обладнання та еміграцію кваліфікованих кадрів), можуть надовго стати депресивними. Тому перед українською владою стоїть серйозний виклик не тільки щодо повернення окупованих територій, а й щодо відновлення їх соціально-економічного потенціалу. Складною є ситуація і на прифронтових територіях Донецької та Луганської областей, підконтрольних Україні, насамперед у сфері критичної інфраструктури, яка є спільною i для підконтрольних, і для непідконтрольних територій, зокрема щодо експлуатації залізничного транспорту, ЛЕП, мостів, газопроводів, водогонів тощо.

В плані подолання міжрегіональних диспропорцій досить гостро стоять проблеми реіндустріалізації більшості центральних і західних областей України. Позитивний приклад в цьому плані показує Закарпатська область, яка розвиває свою промисловість на засадах транснаціоналізації (наприклад, у с. Соломоново на ПрАТ “Сврокар”, що входить до концерну Volkswagen AG, збираються автомобілі марки Skoda). Не знято 3 повістки дня й питання щодо “аграризації” індустріально розвинених областей. Хоча дисбаланси в індустріально-аграрному розвитку областей $\epsilon$ значною мірою об'єктивними та історично зумовленими, однак вони не мають набирати гіпертрофованих форм. Поліпшення ситуації в плані подолання асиметрії в експорті та імпорті товарів сталося, як це не прикро, через війну на Сході країни й, відповідно, скорочення експорту металопродукції з Донецької та Луганської областей. Не віщує нічого доброго в плані подолання міжрегіональних диспропорцій і ситуація в інвестиційній сфері. Навіть без врахування Києва столичний регіон явно перетягує на себе «інвестиційну ковдру». Щоправда, прямі іноземні інвестиції, окрім Києва, щонайбільше осідають в індустріально розвинених областях. За рівнем зайнятості населення в лідери вибилася Харківська область, яка досить успішно розвиває трудомісткі галузі, зокрема машинобудування, що є гарним прикладом для більшості регіонів України, особливо через катастрофічний відтік кваліфікованої робочої сили за кордон. За рівнем заробітної плати в лідерах традиційно після Києва були індустріально розвинені області, і першою - Донецька, а в аутсайдерах - західні (передусім Тернопільська) та північні області. Оскільки заробітна плата складає основу наявного доходу населення, то ситуація щодо груп регіонів-лідерів і регіоніваутсайдерів не може бути принципово іншою, змінюються хіба що позиції окремих регіонів у групах. Однак звертає на себе увагу великий розрив $(73 \%)$ у рівнях доходів на одну особу в українських регіонах навіть у довоєнний період. За міжнародними стандартами він не повинен перевищувати $20 \%$ [3].

Окремі дослідники звертають увагу на феномен невідповідності між економічною потужністю індустріально розвинених регіонів, їх внеском у державний бюджет і гостротою у них соціальних проблем, про що свідчить високий рівень захворюваності та смертності (особливо серед чоловіків працездатного віку), складність криміногенної та екологічної ситуації тощо [4, с. 78]. Звичайно, ці проблеми слід вирішувати швидшими темпами, інакше вони й далі підживлюватимуть сепаратизм на соціальноекономічному грунті. 
Для оцінювання дисбалансів в рівнях розвитку регіонів країни недостатньо розрахунок розмаху міжрегіональної асиметрії $(A p)$, тому що від не характеризує ступінь асиметрії по всій сукупності регіонів. Для цього використовують спеціальні інструменти: коефіцієнти варіації Уільямсона та Лавровського; індекси Джині, Аткінсона, Тейла; криву Лоренца; статистичні оцінки варіації ознак.

Найбільш відомі з математичної статистики такі оцінки варіації (розсіювання) показників рівня розвитку регіонів від їхнього середнього значення: середнє лінійне відхилення $(\bar{d})$, середнє квадратичне відхилення $(\delta)$, коефіцієнт асиметричності $(\gamma)$ та коефіцієнт варіації $(V)$ :

$$
\bar{d}=\frac{\sum\left|x_{i}-\overline{x_{i}}\right|}{n} ; \quad \delta=\sqrt{\frac{\sum\left(x_{i}-\bar{x}_{i}\right)^{2}}{n}} ; \quad \gamma=\frac{\delta}{\bar{d}} ; \quad V=\frac{\delta}{\overline{\tilde{\sigma}}_{i}} \times 100,
$$

де $x_{i}$ - показник рівня розвитку $i$-го регіону; $\bar{x}_{i}-$ середній показник рівня розвитку регіонів; $n$ - кількість регіонів.

3 використання статистичних характеристик варіації дамо оцінку міжрегіональної асиметрії регіонів України за показником ВРП на одну особу за ряд років (табл. 2).

\section{Статистичні характеристики варіації ВРП на одну особу}

Таблиия 2

Table 2

Statistical characteristics of variation of GRP per person

\begin{tabular}{|l|c|c|c|c|}
\hline \multicolumn{1}{|c|}{ Характеристики варіації } & $2000^{1}$ & 2010 & 2013 & $2016^{2}$ \\
\hline Середнє значення показника & 2522 & 20424 & 29081 & 50156 \\
\hline Середнє лінійне відхилення & 675 & 7140 & 9751 & 19075 \\
\hline Середнє квадратичне відхилення & 926 & 11447 & 17464 & 32901 \\
\hline Коефіцієнт асиметрії & 1,372 & 1,603 & 1,791 & 1,725 \\
\hline Коефіцієнт варіації, \% & 36,7 & 56,0 & 60,1 & 65,6 \\
\hline
\end{tabular}

Примітки:

${ }^{1}$ За показником валової доданої вартості на одну особу; ОРДЛО.

22Дані наведено без урахування тимчасово окупованих територій АР Крим, м. Севастополя та

Джерело: складено автором на основі даних Держслужби статистики України.

Коефіцієнти асиметрії та варіації, наведені в табл. 2, вказують на те, що в Україні простежується чітка тенденція до поглиблення міжрегіональних дисбалансів (із врахуванням Києва та Севастополя) за показником ВРП на одну особу. Причин, що зумовлюють поглиблення дисбалансів у соціально-економічному розвитку регіонів, $\epsilon$ достатньо багато - це: недостатнє узгодження на регіональному рівні заходів галузевих політик; невиконання регіональних програм соціально-економічного розвитку навіть в розрізі основних проектів; невідповідність бюджетів розвитку територіальних громад стратегічним пріоритетам розвитку регіонів; недостатня активність міжнародних донорів у сфері регіональної політики. Для нейтралізації причин, що зумовлюють міжрегіональні дисбаланси, необхідним є упровадження адекватних заходів, спрямованих на їх усунення.

3. Подальша поляризачія економічного простору. Поглиблення дисбалансів в соціально-економічному розвитку відмічається не тільки на регіональному рівні, а й у просторі загалом. Це виражається в зростанні різниці між соціально-економічними потенціалами Києва і великих міст (Харкова, Одеси, Дніпра, Донецька - до російської окупації, Львова й інших), з одного боку, та сіл і селищ (загалом сільських територій), малих і середніх міст - 3 іншого. 325 регіональних центрів (без врахування міст Києва і 
128 Захарченко В.І. Передумови проведення та комплексні проблеми...

Севастополя) тільки у 7 протягом останніх 15 років (до російсько-української війни) зафіксовано позитивну динаміку і концентрації населення, і економічної діяльності. Серед міст обласного значення лише 21 з них (або 14 \%) мали позитивну динаміку обох показників, ще 84 міста (57 \%) при збільшенні економічної концентрації демонстрували низхідну динаміку щільності населення. 3-поміж міст районного значення 163 міста $(35,8 \%)$, щонайбільше в центральних і східних регіонах країни, мали низхідну динаміку обох показників [5, с. 125-127].

Згідно досліджень Г. Підгрушного [6, с. 50], із 1320 міських поселень 1163 або 55 \% відносяться до категорії стагнуючих (з від’ємним сальдо міграції, різким спадом економічної активності). Причому найбільше серед них моноспеціалізованих міст. Зрозуміло, що не в кращому стані знаходяться і території у зоні їхнього впливу, зокрема сільські. У 1545 сільських районах знелюднення сіл супроводжується згортанням економічної активності, а кількість сіл, у яких відсутні будь-які суб'єкти господарської діяльності, становить третину від їх загальної кількості [7, с. 14].

Зростання економічної активності та інтеграцію в загальноукраїнський і світовий економічний простір сільських територій і ряду регіонів (АР Крим, Закарпатської і Чернівецької областей, південно-західної частини Одеської області) гальмує їх низька транспортна доступність.

Отже, важливим завданням нової регіональної політики $є$ регулювання метрополізаційних процесів, формування збалансованої системи полюсів економічного зростання та периферійних територій для їх адаптації до умов глобалізації.

4. Неготовність українських регіонів до викликів глобалізації. Глобалізація як процес, що призводить до взаємопов'язування економік, культур та інститутів в усьому світі, вимагає від нової регіональної політики відповідей на такі виклики для українських регіонів, як:

1) адаптаційна готовність до циклічних коливань світової економічної кон'юнктури;

2) інвестиційна привабливість в контексті залучення глобального капіталу;

3) можливості щодо інтеграції у світогосподарські зв'язки та транснаціоналізації економіки;

4) готовність до четвертої промислової революції, що передбачає застосування технологій штучного інтелекту, робототехніки, інтернету речей, автономних транспортних засобів, 3-D друку, блокчейну, біотехнологій тощо в контексті створення високотехнологічного сектору економіки;

5) використання можливостей єдиної комунікаційної мережі Інтернет для покращення доступу до ресурсів, розвитку електронного бізнесу та електронної комерції у глобальному масштабі;

6) лібералізація правил торгівлі та загострення конкуренції на міжнародних ринках;

7) формування “нових економічних" (глобалізованих) регіонів та розширення транскордонного співробітництва, що призводить до відтоку трудових, інтелектуальних та інших ресурсів, зокрема з прикордонних регіонів;

8) наближення національного законодавства 3 питань регіональної політики, зокрема у сфері міжнародних економічних відносин, до міжнародних норм і стандартів.

На більшість із викликів глобалізації регіональна політика в Україні реагує надто слабо. Більше того, навіть за тими викликами, у відповідях на які відмічався значний прогрес, особливо на початку XXI ст. щодо формування глобалізованих регіонів типу спеціальних економічних зон (“Сиваш", “Закарпаття”, “Славутич” та "Курортополіс Трускавець» та ін.) та єврорегіонів (“Карпати”, “Буг”, “Карпати”, “Нижній Дунай” і “Прут”), нині спостерігається стійкий регрес. Кардинально ситуацію може поліпшити 
тільки орієнтація на підвищення конкурентоспроможності, передусім міжнародної, національних регіонів.

5. Невисокий рівень конкурентоспроможності, зокрема міжнародної, українських регіонів. Загальноприйнятими для оцінювання рівня конкурентоспроможності країн і регіонів $є$ методики Всесвітнього економічного форуму (ВЕФ) та міжнародного Інституту розвитку менеджменту (IPM). В Україні до 2014 р. оцінювання конкурентоспроможності країни та іiі регіонів за методикою ВЕФ проводили фахівці українського Фонду “Ефективне управління”. В подальшому, згідно Державної стратегії регіонального розвитку на період до 2020 року, цим мають займатися фахівці Мінрегіону. Розрахунки конкурентоспроможності України за методикою IPM уже тривалий час проводять фахівці Міжнародного інституту менеджменту (Київ). На жаль, систематичні розрахунки конкурентоспроможності українських регіонів за методикою IPM не проводяться. Тільки станом на 2012 р. вони були виконані (за модифікованою методикою IPM) С. Захарченком [8].

Оскільки на офіційному рівні передбачається оцінювання конкурентоспроможності України та їі регіонів за методикою ВЕФ, то наведемо оцінки, індексу глобальної конкурентоспроможності (ІГК), одержані фахівцями Фонду “Ефективне управління". На їх основі розрахуємо розмах міжкраїнної асиметрії (Ак) за $I Г К$, його субіндексами та складовими - як відношення показників найвищого i найнижчого рівнів конкурентоспроможності країн, або середніх показників за регіонами країни (як бази для порівняння). Аналогічно розрахуємо розмах міжрегіональної асиметрії (Ap) - за співвідношеннями показників найвищого і найнижчого рівнів конкурентоспроможності регіонів країни (табл. 3).

\section{Розмах асиметрії рівнів розвитку України та ії регіонів ${ }^{1}$ за індексом глобальної конкурентоспроможності, 2013-2014 pp.}

Table 3

The scope of asymmetry in the levels of development of Ukraine and its regions ${ }^{1}$ according to the Global Competitiveness Index, 2013-2014

\begin{tabular}{|c|c|c|c|c|c|c|c|c|}
\hline \multirow{3}{*}{$\begin{array}{c}\text { Індекс, субіндекси } \\
\text { та складові глобальної } \\
\text { конкурентоспроможності }\end{array}$} & \multirow{3}{*}{$\begin{array}{c}\text { Найвищий } \\
\text { бал серед } \\
\text { країн }\end{array}$} & \multirow{3}{*}{$\begin{array}{l}\text { Середній } \\
\text { бал за } \\
\text { регіонами } \\
\text { України }\end{array}$} & \multirow{3}{*}{$A \kappa^{2}$} & \multicolumn{4}{|c|}{ Регіони України } & \multirow{3}{*}{$A p^{3}$} \\
\hline & & & & \multicolumn{2}{|c|}{$\begin{array}{c}3 \text { найвищим } \\
\text { балом } \\
\end{array}$} & \multicolumn{2}{|c|}{$\begin{array}{c}3 \text { найнижчим } \\
\text { балом }\end{array}$} & \\
\hline & & & & область & бал & область & бал & \\
\hline $\begin{array}{l}\text { Індекс глобальної } \\
\text { конкурентоспроможності }\end{array}$ & 5,67 & 4,01 & 1,41 & м. $\mathbf{K}$ & 4,40 & Кр & 3,83 & 1,15 \\
\hline Субіндекс А: Базові вимоги & $\ldots$ & 4,42 & $\ldots$ & M. $K$ & 4,63 & Km & 4,27 & 1,08 \\
\hline 1. Інституції & 6,10 & 3,83 & 1,59 & $\mathrm{XM}_{\mathrm{M}}$ & 4,00 & M. K & 3,46 & 1,16 \\
\hline 2. Інфраструктура & 6,74 & 3,90 & 1,73 & M. K & 5,12 & $\mathrm{Tp}$ & 3,31 & 1,55 \\
\hline $\begin{array}{l}\text { 3. Макроекономічне } \\
\text { середовище }\end{array}$ & 7,00 & 4,20 & 1,67 & всі 27 & 4,20 & всі 27 & 4,20 & 1,00 \\
\hline $\begin{array}{l}\text { 4. Охорона здоров'я та } \\
\text { початкова освіта }\end{array}$ & 6,82 & 5,75 & 1,19 & Кв & 5,97 & Kp & 5,52 & 1,08 \\
\hline $\begin{array}{l}\text { Субіндекс В: Підсилювачі } \\
\text { ефективності }\end{array}$ & $\cdots$ & 3,79 & ... & M. $K$ & 4,36 & $\kappa p$ & 3,55 & 1,23 \\
\hline $\begin{array}{l}\text { 5. Вища освіта та професійна } \\
\text { підготовка }\end{array}$ & 6,27 & 4,55 & 1,38 & Хрк & 5,28 & Kp & 4,08 & 1,29 \\
\hline 6. Ефективність ринку товарів & 5,59 & 4,12 & 1,36 & Од & 4,26 & $\mathrm{Tp}$ & 4,01 & 1,06 \\
\hline 7. Ефективність ринку праці & 5,77 & 4,63 & 1,25 & $\mathrm{XM}$ & 4,80 & $\mathrm{Xpc}$ & 4,42 & 1,09 \\
\hline $\begin{array}{l}\text { 8. Рівень розвитку } \\
\text { фінансового ринку }\end{array}$ & 6,02 & 4,12 & 1,46 & $\mathrm{CM}$ & 4,26 & Мк & 3,92 & 1,09 \\
\hline 9. Технологічна готовність & 6,22 & 3,11 & 2,00 & M. K & 4,38 & Лг & 2,78 & 1,58 \\
\hline 10. Розмір ринку & 6,94 & 2,21 & 3,14 & M. K & 3,71 & M. C & 1,27 & 2,92 \\
\hline
\end{tabular}


130 Захарченко В.І. Передумови проведення та комплексні проблеми...

Продовження табл.3

\begin{tabular}{|l|c|c|c|c|c|c|c|c|}
\hline $\begin{array}{l}\text { Субіндекс С: Фактори } \\
\text { розвитку та інноваційного } \\
\text { потенціалу }\end{array}$ & $\ldots$ & $\mathbf{3 , 5 0}$ & $\boldsymbol{\ldots}$ & $\boldsymbol{X p \kappa}$ & $\mathbf{3 , 9 1}$ & $\boldsymbol{W m}$ & $\mathbf{3 , 2 3}$ & $\mathbf{1 , 2 1}$ \\
\hline 11. Рівень розвитку бізнесу & 5,75 & 3,96 & 1,45 & Днц & 4,25 & Жт & 3,79 & 1,12 \\
\hline 12. Інновації & 5,79 & 3,04 & 1,90 & Хрк & 3,60 & Жт & 2,67 & 1,35 \\
\hline
\end{tabular}

Примітки:

${ }^{1}$ Використано скорочення назв областей, наведені в табл. 1, а також додаткові скорочення: Мк Миколаївська область, См - Сумська область, м. К - місто Київ, м. С - місто Севастополь;

${ }^{2} A \kappa$ - розмах міжкраїнної асиметрії конкурентоспроможності;

${ }^{3} \mathrm{Ap}$ - розмах міжрегіональної асиметрії конкурентоспроможності.

Дюеерело: складено автором на основі [9, с. 31, 125-231].

Як видно з табл. 3, асиметрія рівнів конкурентоспроможності України та іï регіонів за $I Г К$, його субіндексами та складовими $є$ не настільки глибокою як за окремими показниками рівня їхнього розвитку (див. табл. 1). Це пояснюється тим, що $I Г K$, його субіндекси та складові розраховуються з використанням багатьох показників, тому навіть дуже важливі показники, такі як ВВП та ВРП на одну особу, “гасяться" менш важливими, але 3 вищими значеннями. Значний розрив у показниках конкурентоспроможності міст 3 особливим статусом (Києва і Севастополя) за розмірами ринків не має принципового значення, бо вони сильно відрізняються між собою за чисельністю жителів. Натомість розриви в рівнях технологічної готовності Києва і Луганської області, упровадження інновацій у Харківській та Житомирській областях дуже важливі, бо без нарощування інноваційного потенціалу переважної більшості регіонів ймовірність підвищення їх міжнародної конкурентоспроможності дуже мала. Примітно, що немає глибокої диференціації регіонів за рівнем розвитку у них бізнесу. Однак це легко пояснюється тим, що він недостатньо розвинений у більшості з них, що вказує на проблеми українських регіонів у плані саморозвитку, на вирішенні яких робиться акцент у парадигмі нового регіоналізму. Низький рівень розвитку інфраструктури в Тернопільській та ряді інших областей не сприяє їх прискореному соціально-економічному розвитку, а тому потребує застосування окремих елементів механізму старого регіоналізму, який передбачає пряму фінансову допомогу держави таким регіонам.

Тільки за високого рівня конкурентоспроможності українських регіонів можна досягти в них високого рівня людського розвитку (доходів, освіти, тривалості життя) у міжнародному вимірі - за Індексом людського розвитку (IЛP), методика розрахунку була розроблена в рамках Програми розвитку $\underline{\mathrm{OOH}}$. В Україні для оцінювання рівня людського розвитку регіонів фахівцями Держслужби статистики й Інституту демографії та соціальних досліджень НАН України запропоновано регіональний варіант IЛР - Індекс регіонального людського розвитку (ІРЛР), що розраховується на основі 33 показників, зведених у 6 субіндексів.

Розрахунки IРЛР та його субіндексів показують, що міжрегіональні диспропорції загалом $є$ не такими виразними як за $I Г K$, його субіндексами і складовими. Це пояснюється тим, що для розрахунку IРЛР та його субіндексів використовуються стандартизовані значення вихідних показників (табл. 4).

3 табл. 4 видно, що найбільший IРЛР до війни на Сході країни (у 2013 р.) мала Харківська область, а найменший - Житомирська. Але у 2017 р. першу позицію вже займала Чернівецька область (за рахунок найвищих показників субіндекса добробуту та високих значень субіндекса відтворення населення), а на останнє місце перемістилася Кіровоградська область. За цей період міжрегіональна асиметрія за IPЛP дещо скоротилася, що $є$ позитивною тенденцією. 


\section{Розмах та динаміка міжрегіональної асиметрії в Україні за індексом та субіндексами регіонального людського розвитку}

Table 4

The scope and dynamics of inter-regional asymmetry in Ukraine by the index and sub-indices of regional human development

\begin{tabular}{|c|c|c|c|c|c|c|c|c|}
\hline \multirow{2}{*}{\multicolumn{2}{|c|}{ ІРЛР та й }} & \multicolumn{3}{|c|}{2013 p. } & \multicolumn{3}{|c|}{2017 p. $^{1}$} & \multirow{2}{*}{$\begin{array}{c}\text { Темп } \\
\text { зростання } \\
\text { асиметрії }\end{array}$} \\
\hline & & область ${ }^{2}$ & \multirow{2}{*}{$\begin{array}{c}\text { значення } \\
\text { показників }\end{array}$} & \multirow{3}{*}{$\begin{array}{c}A p^{3} \\
1,207\end{array}$} & \multirow{2}{*}{$\begin{array}{c}\text { область } \\
\text { Чрн }\end{array}$} & \multirow{2}{*}{$\begin{array}{c}\text { значення } \\
\text { показників } \\
4,2294 \\
\end{array}$} & \multirow{3}{*}{$\begin{array}{l}A p \\
200\end{array}$} & \\
\hline \multirow[t]{2}{*}{ IPЛР } & $\max$ & Хрк & & & & & & \multirow{2}{*}{0,994} \\
\hline & $\min$ & Km & 3,4901 & & $K p$ & 3,5257 & & \\
\hline \multirow[t]{2}{*}{ Відтворення } & $\max$ & $\mathrm{Tp}$ & 0,7372 & \multirow[b]{2}{*}{1,149} & Пл & 0,7725 & \multirow[b]{2}{*}{1,248} & \multirow[b]{2}{*}{1,086} \\
\hline & $\min$ & Кр & 0,6418 & & $\mathrm{Kp}$ & 0,6189 & & \\
\hline \multirow[t]{2}{*}{ Соціальне } & $\max$ & Лв & 0,7104 & \multirow[b]{2}{*}{2,043} & Лв & 0,7732 & \multirow[b]{2}{*}{2,070} & \multirow[b]{2}{*}{1,013} \\
\hline & $\min$ & $\mathrm{Xp}$ & 0,3478 & & Кр & 0,3735 & & \\
\hline \multirow[t]{2}{*}{ Комфортне } & $\max$ & Зк & 0,7896 & \multirow[b]{2}{*}{1,565} & 3к & 0,7045 & \multirow[b]{2}{*}{1,286} & \multirow[b]{2}{*}{0,822} \\
\hline & $\min$ & $\mathrm{XM}$ & 0,5046 & & Зп & 0,5478 & & \\
\hline \multirow[t]{2}{*}{ Добробут } & $\max$ & ЗП & 0,8777 & \multirow{2}{*}{1,876} & Чрн & 0,8705 & \multirow{2}{*}{1,833} & \multirow{2}{*}{0,977} \\
\hline & $\min$ & $\mathrm{PB}_{\mathrm{B}}$ & 0,4679 & & Рв & 0,4749 & & \\
\hline \multirow[t]{2}{*}{ Гідна праця } & $\max$ & Од & 0,6521 & \multirow{2}{*}{1,257} & Зк & 0,5731 & \multirow{2}{*}{1,293} & \multirow{2}{*}{1,029} \\
\hline & $\min$ & $\mathrm{Tp}$ & 0,5188 & & PB & 0,4434 & & \\
\hline \multirow[t]{2}{*}{ Освіта } & $\max$ & Днп & 0,8531 & \multirow{2}{*}{1,175} & Хрк & 0,8704 & \multirow{2}{*}{1,146} & \multirow{2}{*}{0,975} \\
\hline & $\min$ & $3 \kappa$ & 0,7261 & & $3 \kappa$ & 0,7592 & & \\
\hline
\end{tabular}

Примітки: ОРДЛО;

${ }^{1}$ Дані наведено без урахування тимчасово окупованих територій АР Крим, м. Севастополя та

${ }^{2}$ Використано скорочення назв областей, наведені в табл. 1, а також додаткове скорочення: Лв Львівська область;

${ }^{3} \mathrm{Ap}$ - розмах міжрегіональної асиметрії за IРЛР та його субіндексами.

Джерело: складено автором на основі [10, с. 44, 71].

В розрізі субіндексів ІРЛР найбільша міжрегіональна асиметрія спостерігається за субіндексами соціального середовища (розраховується за станом суспільного здоров'я, соціального самопочуття, соціальної напруги й безпеки) й добробуту. Причому за першим субіндексом асиметрія між регіонами зростає, що свідчить про дальше розповсюдження таких негативних явищ, як злочинність, проституція, соціальне сирітство, алкоголізм, наркоманія тощо.

Повну картину динаміки регіонального людського розвитку в Україні можна скласти за даними статистичного збірника [10]. Відштовхуючись від них, слід передбачити заходи, які забезпечать усім жителям регіонів країни доступ до ресурсів, необхідних для досягнення високої якості життя, що, власне, і є кінцевою метою нової регіональної політики.

Висновки. Реалізація в Україні нової регіональної політики, яка базується на парадигмі нового регіоналізму, натикається на значні труднощі, викликані з російською агресією, активізацією процесів глобалізації та регіоналізації, загостренням протиріч між регіонами. У зв'язку з цим необхідно вирішити ряд комплексних проблем нової регіональної політики, пов'язаних 3 політичною та економічною дезінтеграцією українських регіонів, поглибленням асиметрії в соціально-економічному розвитку регіонів, поляризацією економічного простору, неготовністю регіонів до викликів 
132 Захарченко В.І. Передумови проведення та комплексні проблеми...

глобалізації, невисоким рівнем регіональної конкурентоспроможності й, відповідно, регіонального людського розвитку.

1. Ткачук А. Ф. Державна регіональна політика: від асиметрії до солідарності (робочий зошит). Київ: ІКЦ “Легальний статус", 2013. 112 с.

2. Моніторинг соціально-економічного розвитку регіонів України за 2001 рік. Київ: Мінекономіки та з питань європ. інтегр. України, 2002. 174 с.

3. Данилишин Б. Регіоналізм в Україні: реальність і перспективи. Дзеркало тижня. 2012. № 22, 15 черв. URL: https://dt.ua/POLITICS/regionalizm__v_ukrayini_realnist_i_perspektivi.html (дата звернення: 28.09.2019).

4. Регіональний розвиток та державна регіональна політика в Україні: стан і перспективи змін $y$ контексті глобальних викликів та європейських стандартів політики: аналіт. звіт / [К. Меддок та ін.]; Проект ЄС “Підтримка політики регіонального розвитку в Україні”. Київ: [б. в.], 2014. 416, [32] c. URL: http://surdp.eu/uploads/files/Analytical_Report_Main_part_UA.pdf (дата звернення: 28.09.2019).

5. Романюк С. А. Розвиток регіонів у відкритій економіці: теорія, політика, практика: монографія. Київ: НАДУ, 2013. 408 с.

6. Підгрушний Г. П. Формування системи полюсів зростання в Україні як передумова ії переходу до моделі поліцентричного просторового розвитку. Украӥнський географічний журнал. 2017. № 1. С. $48-54$.

7. Романюк С. А. Регіональний розвиток і децентралізація: теоретичні та практичні аспекти. Регіональна економіка. 2016. № 3. С. 10-18.

8. Захарченко С.В. Конкурентоспроможність України та іiі регіонів: міжнародний вимір: монографія. Вінниця: Консоль, 2016. 413 с.

9. Звіт про конкурентоспроможність регіонів України 2013: Назустріч економічному зростанню та процвітанню / Т. Бойко, І. Гончаренко, Н. Дмитрюк та ін. Київ: Фонд "Ефективне управління", 2013. http://debaty.org/uploadfiles/ckfinder/files/reports/2013/FEG_report_2013_body_ukr_web.pdf (дата звернення: 28.09.2019).

10. Регіональний людський розвиток: стат. зб. / відп. за вип. О. О. Кармазіна. Київ: Держслужба статистики України, 2018. 72 с.

\section{References}

1. Tkachuk, A. F. State regional policy: from asymmetry to solidarity (workbook), Legal Status ICC, 2013.

2. Monitoring of socio-economic development of Ukrainian regions for 2001, Ministry of Economy and European Integration of Ukraine, 2002.

3. Danylyshyn, B. "Regionalism in Ukraine: reality and prospects". The mirror of the week, no. 22, 15 June, 2012. ZN.ua,_dt.ua/POLITICS/regionalizm V u ukrayini_realnist_i_perspektivi.html. Accessed 28 Sept. 2019.

4. Regional development and national regional policy in Ukraine: the state and prospects of change in the context of global challenges and European policy standards: an analyst. Report, 2014. Support of regional development policy in Ukraine, surdp.eu/uploads/files/Analytical_Report_Main_part_UA.pdf. Accessed 28 Sept. 2019.

5. Romaniuk, S. A. Development of regions in an open economy: theory, policy, practice: monograph, NADU, 2013.

6. Podgrushny, G. P. "Formation of the system of growth poles in Ukraine as a prerequisite for its transition to a model of polycentric spatial development". Ukrainian Geographical Journal, no. 1, 2017, pp. 48-54.

7. Romaniuk, S. A. "Regional development and decentralization: theoretical and practical aspects". Regional economy, no. 3, 2016, pp. 10-18.

8. Zakharchenko, S. V. Competitiveness of Ukraine and its regions: international dimension: monograph, Console, 2016.

9. Boyko, T., Goncharenko, I., Dmytryuk, N., etc. Competitiveness Report of Regions of Ukraine 2013: Towards Economic Growth and Prosperity, Foundation for Effective Governance, 2013. Debaty, debaty.org/uploadfiles/ckfinder/files/reports/2013/FEG_report_2013 body_ukr_web.pdf. Accessed 28 Sept. 2019.

10. Regional Human Development, State Statistics Service of Ukraine, 2018. 